\title{
Sistem Pakar Untuk Mendeteksi Kerusakan Pada Sepeda Motor 4-tak Dengan Menggunakan Metode Backward Chaining
}

\author{
Maria Shusanti F \\ Program Studi Teknik Informatika \\ Fakultas Ilmu Komputer \\ Universitas Bandar Lampung \\ Jln. Z.A. Pagar Alam No.26 Labuhan Ratu Bandar Lampung 35142 \\ Telp. (0721) 701463, (0721) 701979 Fax. (0721) 701467 Web. www.ubl.ac.id
}

\begin{abstract}
Abstrak
Kendaraan sepeda motor merupakan suatu alat transportasi yang banyak digunakan masyarakat pada umumnya. Pertumbuhan jumlah sepeda motor sangat pesat seiring dengan tingkat ekonomi dan kebutuhan masyarakat terhadap alat transportasi yang murah dan terjangkau sehingga banyak masyarakat yang memilih sepeda motor 4-tak sebagai kendaraan pribadinya untuk digunakan dalam aktivitas sehari-hari.

Penelitian ini akan menggambarkan serta menjelaskan sistem pakar yang akan digunakan untuk mendeteksi kerusakan sepeda motor 4-tak dengan menggunakan metode backward chaining dengan jelas. Peneliti akan menggunakan metode backward chaining sebagai metode inferensi untuk sistem pakar ini. Penjelasan mengenai sistem pakar untuk mendeteksi kerusakan sepeda motor 4-tak dengan menggunakan metode backward chaining akan dijelaskan pada bab IV penelitian ini.
\end{abstract}

Kata kunci : sistem pakar, sepeda motor 4-tak, backward chaining

\section{PENDAHULUAN}

Teknologi semakin berkembang pesat dengan seiring berjalannya waktu. Salah satu teknologi yang mengalami perkembangan pesat adalah Komputer. Komputer yang pada awalnya digunakan sebagai alat hitung, seiring dengan perkembangan jaman komputer banyak digunakan di berbagai bidang, misalnya pada bidang militer, ekonomi, dan sebagainya. Salah satu pemanfaatan teknologi komputer yaitu dapat digunakan untuk sistem pakar. Sistem pakar merupakan suatu pemodelan dari proses penalaran seorang pakar yang memiliki pengetahuan tertentu, agar keahlian si pakar dapat dimanfaatkan oleh masyarakat awam atau orang-orang yang non-pakar. Penggunaan sistem pakar antara lain untuk: konsultasi, melakukan analisis dan diagnosis, membantu pengambilan keputusan, dan lain-lain. Umumnya sistem pakar dirancang untuk berinteraksi langsung dengan pemakai dalam format dialog (tanya-jawab). Dialog tersebut dapat memberikan keputusan sesuai penalaran. Oleh karena itu, sistem pakar (expert system) mempunyai kemampuan untuk memudahkan masalah-masalah praktis pada saat sang pakar berhalangan.

Kendaraan sepeda motor merupakan suatu alat transportasi yang banyak digunakan masyarakat pada umumnya. Pertumbuhan jumlah sepeda motor sangat pesat seiring dengan tingkat ekonomi dan kebutuhan masyarakat terhadap alat transportasi yang murah dan terjangkau. Namun, seiring semakin banyaknya pengguna motor di jalanan, ternyata menimbulkan masalah baru, yaitu pencemaran lingkungan berupa polusi udara. Sepeda motor yang menimbulkan banyak asap adalah sepeda motor 2-tak karena itu masyarakat mulai beralih ke sepeda motor 4-tak yang dikenal lebih ramah lingkungan serta irit dalam pemakaian bahan bakar sehingga banyak masyarakat modern cenderung memilih sepeda motor 4-tak sebagai kendaraan pribadinya. Pengguna sepeda motor 4-tak yang semakin banyak menyebabkan meningkatnya usaha-usaha 
yang berhubungan dengan sepeda motor 4-tak, salah satunya adalah usaha perbaikan sepeda motor 4-tak. Perkembangan usaha ini yang semakin maju dan meluas tidak diiringi dengan perkembangan tenaga ahli atau pakar yang menguasai keahlian untuk memperbaiki sepeda motor untuk memperbaiki sepeda motor 4-tak. Permintaan konsumen yang meningkat di sebuah bengkel tidak dapat diatasi dengan tenaga ahli yang sedikit. Dengan kecerdasan buatan (sistem pakar) memungkinkan sebuah bengkel untuk mengatasi kekurangan tenaga ahli dalam mendeteksi kerusakan sepeda motor 4-tak milik si konsumen sehingga dapat dengan cepat dilakukan penanganan dalam menanggulangi kerusakkan dengan tepat.

\subsection{Identifikasi Masalah}

Dari latar belakang yang telah diungkapkan di atas dapat dilihat bahwa sepeda motor merupakan salah satu kendaraan utama bagi masyarakat indonesia. Sepeda motor yang umum digunakan adalah sepeda motor 4-tak karena memiliki keunggulan ramah lingkungan serta hemat bahan bakar bila dibandingkan dengan sepeda motor 2tak yang sering dijadikan "kambing hitam" atas polusi udara yang terjadi. Pengguna sepeda motor 4-tak yang semakin banyak menyebabkan meningkatnya usaha-usaha yang berhubungan dengan sepeda motor 4-tak, salah satunya adalah usaha perbaikan sepeda motor 4-tak. Perkembangan usaha ini yang semakin maju dan meluas tidak diiringi dengan perkembangan tenaga ahli atau pakar yang menguasai keahlian untuk memperbaiki sepeda motor 4-tak. Permintaan konsumen yang meningkat di sebuah bengkel tidak dapat diatasi dengan tenaga ahli yang sedikit.

\subsection{Perumusan Masalah}

Berdasarkan identifikasi masalah tersebut, maka peneliti merumuskan permasalahan yang muncul adalah " Apakah dengan adanya sistem pakar ini yang dirancang menggunakan metode backward chaining dapat digunakan sebagai tenaga ahli pengganti untuk mendeteksi kerusakan sepeda motor 4-tak? “. Melihat perumusan masalah di atas, maka peneliti membatasi masalah yang akan dibahas dalam penelitian ini hanya dalam mendeteksi kerusakan sepeda motor 4-tak serta memberikan solusi atas kerusakan dengan merancang perangkat lunak (software) sistem pakar untuk mendeteksi kerusakan sepeda motor 4-tak menggunakan metode backward chaining.

\subsection{Tujuan Penelitian}

Adapun penelitian penelitian ini memiliki tujuan sebagai berikut:

1. Merancang suatu perangkat lunak yang dapat menggantikan tenaga ahli atau pakar sepeda motor 4-tak.

2. Merancang suatu perangkat lunak yang dapat mendiagnosa kerusakan sepeda motor 4-tak.

\subsection{Manfaat Penelitian}

Adapun penelitian penelitian ini diharapkan dapat memberi manfaat, diantaranya :

1. Meningkatkan kinerja dari suatu bengkel dalam mengatasi permintaan konsumen yang meningkat.

2. Diharapkan dapat juga digunakan sebagai sarana pelatihan bagi tenaga ahli atau pakar dalam mendeteksi kerusakan sepeda motor 4-tak.

\section{LANDASAN TEORI}

\subsection{Kecerdasan Buatan Secara Umum}

Kecerdasan buatan dapat didefinisikan sebagai mekanisme pengetahuan yang ditekankan pada kecerdasan pembentukan dan penilaian pada alat yang menjadikan mekanisme itu, serta membuat komputer berpikir secara cerdas. Kecerdasan buatan juga dapat didefinisikan sebagai salah satu bagian ilmu komputer yang membuat agar mesin (komputer) dapat melakukan pekerjaan seperti dan sebaik yang dilakukan manusia. Agar komputer bisa bertindak seperti dan sebaik manusia, maka komputer juga harus diberi bekal pengetahuan, dan mempunyai kemampuan untuk menalar. Kecerdasan dapat dilihat dari berbagai sudut pandang antara lain :

1. Sudut pandang kecerdasan Kecerdasan buatan akan membuat mesin menjadi cerdas

2. Sudut pandang penelitian Kecerdasan buatan adalah suatu studi bagaimana membuat agar komputer dapat melakukan sesuatu sebaik yang dikerjakan manusia

3. Sudut pandang bisnis Kecerdasan buatan adalah kumpulan peralatan yang sangat powerful dan metodologis dalam menyelesaikan masalah-masalah bisnis.

4. Sudut pandang pemrograman 
Kecerdasan buatan meliputi studi tentang pemrograman simbolik, penyelesaian masalah, dan pencarian. Untuk melakukan aplikasi kecerdasan buatan ada 2 bagian utama yang sangat dibutuhkan, yaitu :

a. Basis Pengetahuan, berisi fakta-fakta, teori, pemikiran dan hubungan antara satu dengan lainnya

b. Motor inferensi, yaitu kemampuan menarik kesimpulan berdasarkan pengalaman.

\subsection{Sistem Pakar}

\subsubsection{Pengertian Sistem Pakar}

Pakar adalah seorang ahli adalah seseorang yang mampu menjelaskan suatu tanggapan, mempelajari hal-hal baru seputar topik permasalahan (domain), menyusun kembali pengetahuan jika dipandang perlu, memecah aturan-aturan jika dibutuhkan, dan menentukan relevan tidaknya keahlian mereka. Misalnya ahli farmasi (dalam bidang farmasi), dokter (dalam bidang kedokteran), dan lain-lain. Sistem adalah sekumpulan unsur / elemen yang saling berkaitan dan saling mempengaruhi dalam melakukan kegiatan bersama untuk mencapai suatu tujuan. Sistem pakar (expert system) secara umum adalah sistem yang berusaha mengadopsi pengetahuan manusia ke komputer, agar komputer dapat menyelesaikan masalah seperti yang biasa dilakukan oleh para ahli. Atau dengan kata lain sistem pakar adalah sistem yang didesain dan diimplementasikan dengan bantuan bahasa pemrograman tertentu untuk dapat menyelesaikan masalah seperti yang dilakukan oleh para ahli. Diharapkan dengan sistem ini, orang awam dapat menyelesaikan masalah tertentu baik 'sedikit' rumit ataupun rumit sekalipun 'tanpa' bantuan para ahli dalam bidang tersebut. Sedangkan bagi para ahli, sistem ini dapat digunakan sebagai asisten yang berpengalaman. Sistem pakar merupakan cabang dari Artificial Intelligence (AI) yang cukup tua karena sistem ini telah mulai dikembangkan pada pertengahan tahun 1960. Sistem pakar yang muncul pertama kali adalah General-purpose problem solver (GPS) yang dikembangkan oleh Newl dan Simon. Sampai saat ini sudah banyak sistem pakar yang dibuat, seperti MYCIN, DENDRAL, XCON \& XSEL, SOPHIE, Prospector, FOLIO, DELTA, dan sebagainya. Tujuan Sistem Pakar adalah untuk mentransfer kepakaran dari seorang pakar ke komputer, kemudian ke orang lain (yang bukan pakar). (Sri Kusumadewi, 2003 : 109-110)

\subsubsection{Manfaat Dan Keterbatasan Sistem Pakar}

Sistem Pakar menjadi sangat populer disebabkan oleh sangat banyaknya kemampuan dan manfaat yang diberikan oleh Sistem Pakar, di antaranya:

a. Meningkatkan output dan produktivitas, karena Sistem Pakar dapat bekerja lebih cepat dari manusia.

b. Meningkatkan kualitas, dengan memberi nasehat yang konsisten dan mengurangi kesalahan.

c. Mampu menangkap kepakaran yang sangat terbatas.

d. Dapat beroperasi di lingkungan yang berbahaya.

e. Memudahkan akses ke pengetahuan.

f. Handal. Sistem Pakar tidak pernah menjadi bosan dan kelelahan atau sakit. Sistem Pakar juga secara konsisten melihat semua detil dan tidak akan melewatkan informasi yang relevan dan solusi yang potensial.

g. Meningkatkan kapabilitas sistem terkomputerisasi yang lain. Integrasi Sistem Pakar dengan sistem komputer lain membuat lebih efektif, dan mencakup lebih banyak aplikasi

\subsubsection{Komponen Sistem Pakar}

Sebuah program yang difungsikan untuk menirukan seorang pakar manusia harus bisa melakukan hal-hal yang dapat dikerjakan seorang pakar. Untuk membangun sistem seperti itu maka komponen-komponen dasar yang harus dimilikinya adalah sebagai berikut:

1. Basis Pengetahuan (Knowledge Base) Basis pengetahuan merupakan inti dari suatu sistem pakar, yaitu berupa representasi pengetahuan dari pakar.

2. Mesin Inferensi (Inference Engine) Mesin inferensi berperan sebagai otak dari sistem pakar. Mesin inferensi berfungsi 
untuk memandu proses penalaran terhadap suatu kondisi, berdasarkan pada basis pengetahuan yang tersedia.

3. Antarmuka Pemakai (User Interface) Fasilitas ini digunakan sebagai perantara komunikasi antara pemakai dengan komputer. ( Ir. Balza Ahmad, M.Sc.E, 2006 , Kecerdasan Buatan )

\subsubsection{Metode Inferensi}

Komponen ini mengandung mekanisme pola pikir dan penalaran yang digunakan oleh pakar dalam menyelesaikan suatu masalah. Metode inferensi adalah program komputer yang memberikan metodologi untuk penalaran tentang informasi yang ada dalam basis pengetahuan dan untuk memformulasikan kesimpulan.

Terdapat dua pendekatan untuk mengontrol inferensi dalam sistem pakar berbasis aturan, yaitu pelacakan ke belakang (Backward chaining) dan pelacakan ke depan (forward chaining).

\section{a. Pelacakan ke belakang (Backward Chaining atau Backward Reasoning)}

Pelacakan ke belakang adalah pendekatan yang dimotori oleh tujuan atau hipotesis (goaldriven). Dalam pendekatan ini penalaran dimulai dari tujuan atau hipotesis terlebih dahulu, kemudian baru dicocokkan dengan keadaan awal atau faktafakta yang ada.

Sifat-sifat backward chaining adalah :

1. Baik untuk Diagnosis.

2. Tampak dari sekarang ke masa lalu.

3. merupakan goal-driven.

4. Bekerja mundur untuk menemukan faktafakta yang mendukung hipotesis.

\subsubsection{Bentuk Sistem Pakar}

Ada 4 bentuk system pakar, yaitu:

1. Berdiri sendiri. Sistem pakar jenis ini merupakan software yang berdiri-sendiri tidak tergantung dengan software yang lainnya.

2. Tergabung. Sistem pakar jenis ini merupakan bagian program yang terkandung didalam suatu algoritma (konvensional), atau merupakan program dimana didalamnya memanggil algoritma subrutin lain (konvensional).
3. Menghubungkan ke software lain . Bentuk ini biasanya merupakan sistem pakar yang menghubungkan ke suatu paket program tertentu, misalnya DBMS.

4.Sistem Mengabdi. Sistem pakar merupakan bagian dari komputer khusus yang dihubungkan dengan suatu fungsi tertentu. Misalnya sistem pakar yang digunakan untuk membantu menganalisis data radar. (Sri Kusumadewi, 2003 : 113)

\section{Perancangan dan Implementasi 3.1 Perancangan Basis Dialog}

Menu dibuat untuk memudahkan pengguna mengakses sistem sesuai dengan fungsinya masing-masing. Menu-menu disusun berdasarkan hierarki tertentu dan setiap menu memiliki sub menu. Untuk pengguna non-pakar, menu utama yang disediakan adalah menu konsultasi. Struktur menu untuk pengguna non-pakar adalah sebagai berikut:

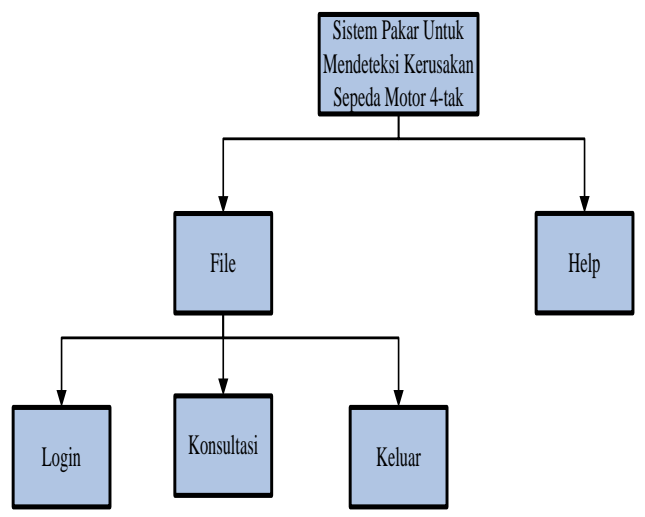

Gambar 3.1.1 Struktur Menu Non Pakar

\subsection{Perancangan Antarmuka}

Berikut adalah rancangan antarmuka sistem pakar untuk mendeteksi kerusakan sepeda motor 4-tak dengan metode backward chaining yang terdiri dari menu utama, rancangan output dan rancangan input : 


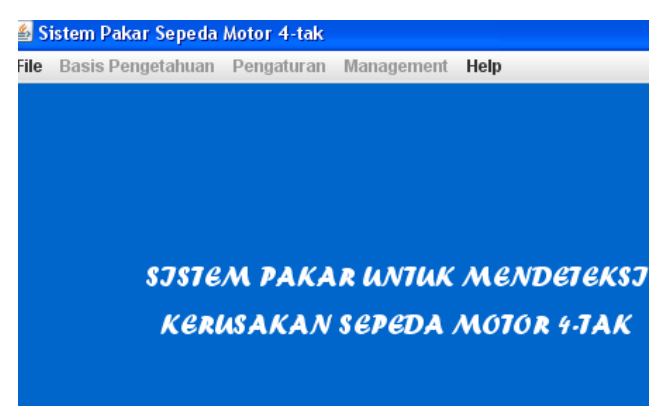

Gambar 3.2.1 Layar Menu Utama

Layar utama bagi pengguna untuk menggunakan perangkat lunak

\subsection{Rancangan Output}

1. Layar Jenis Kerusakan

Sebagai layar bagi pengguna untuk memilih jenis kerusakan dari sepeda motor miliknya.

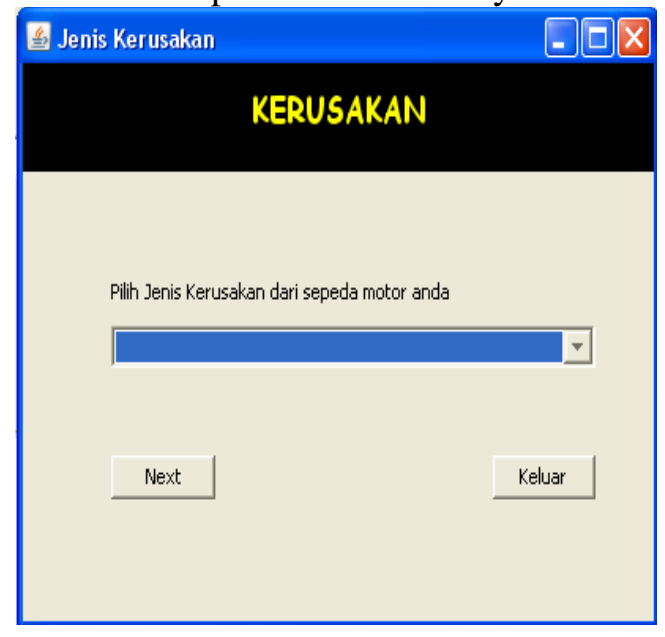

Gambar 3.3.1 Layar Jenis Kerusakan

2. Layar Hipotesa

Sebagai layar bagi pengguna untuk memilih hipotesa yang mendekati kerusakan dari sepeda motor miliknya.

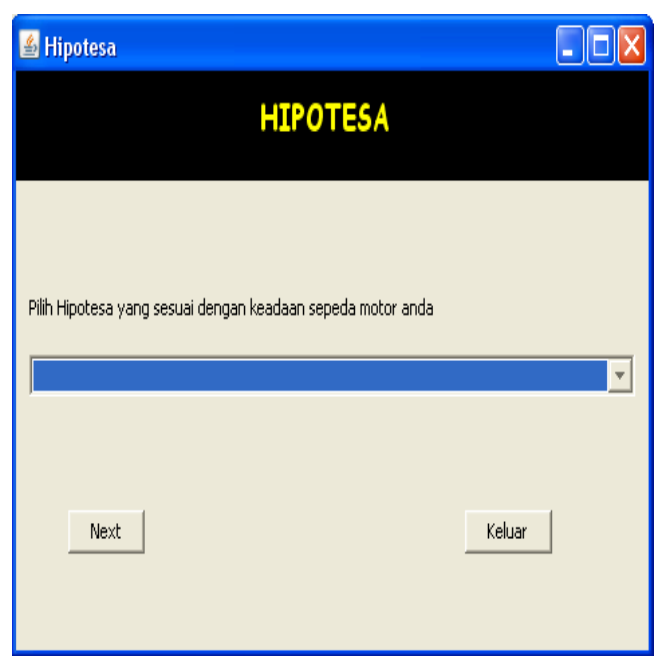

Gambar 3.3.2 Layar Hipotesa Kerusakan

Berfungsi sebagai antarmuka untuk menanyakan pengguna mengenai Pertanyaan-Pertanyaan yang dialami

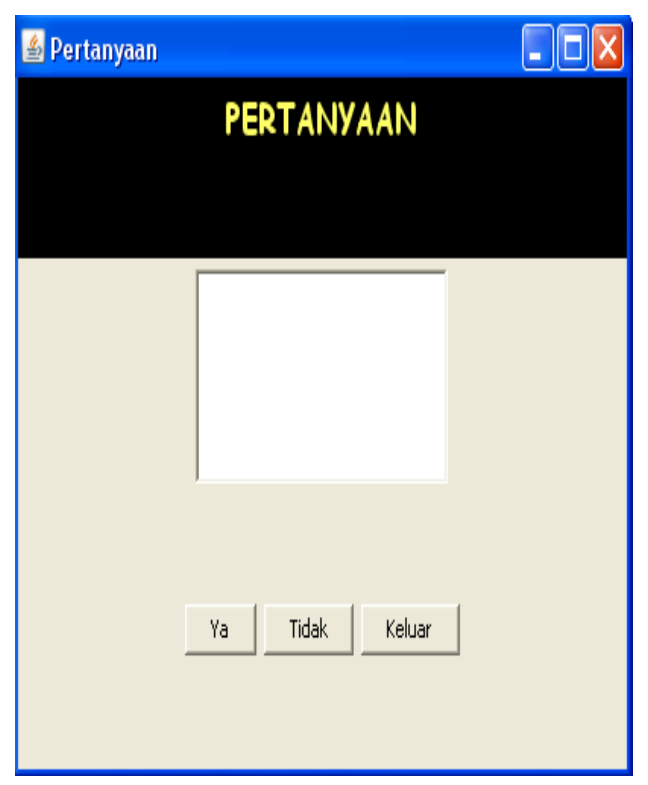

Gambar 3.3.3 Layar Pertanyaan

4. Layar Solusi

Layar ini berfungsi untuk menampilkan solusi dari hasil konsultasi dan juga dapat melakukan pencetakan hasil konsultasi. 


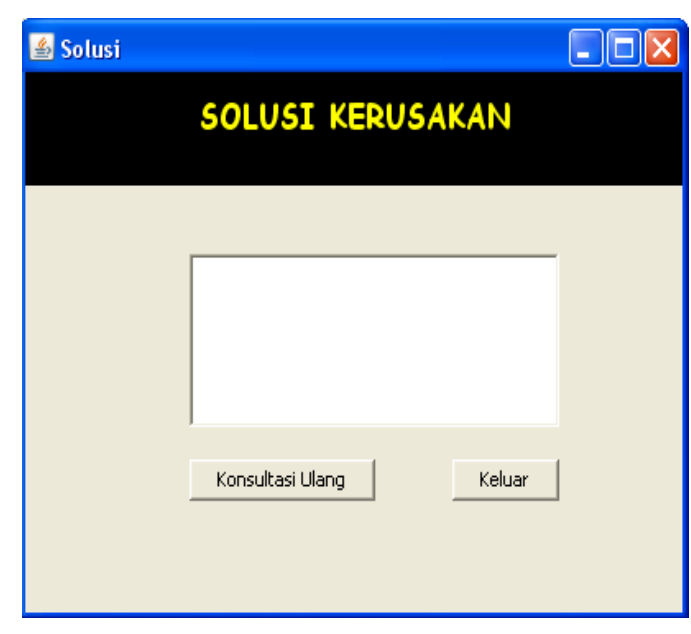

Gambar 3.3.4 Layar Solusi

\subsection{SARAN DAN KESIMPULAN 4.4.1 Simpulan}

Berdasarkan tugas akhir yang dibuat peneliti tentang Sistem Pakar Untuk Mendeteksi Kerusakan Sepeda Motor 4-tak Dengan Menggunakan Metode Backward Chaining yang telah di uraikan dari Bab I sampai Bab IV, maka dapat di ambil kesimpulan bahwa sistem pakar untuk mendeteksi kerusakan sepeda motor 4-tak dengan menggunakan metode backward chaining dapat menggantikan tenaga ahli atau pakar dalam mendeteksi kerusakan sepeda motor 4-tak sehingga kerusakan tersebut dapat diatasi dengan cepat. Selain itu dengan adanya fitur untuk menambah pengetahuan yang hak aksesnya diberikan kepada pengguna pakar maka sistem pakar ini akan dapat terus berkembang sesuai dengan keadaan dan kebutuhan. Kelebihan dari penggunaan metode backward chaining adalah metode ini memiliki sifat yang cocok dalam melakukan diagnosa dan dalam pencarian solusi menggunakan metode ini tidak memerlukan waktu yang lama bila pengguna memberikan informasi yang tepat, tetapi sebaliknya metode ini memiliki kelemahan dalam pencarian solusi, bila pemilihan hipotesa atau kesimpulan tidak tepat maka si pengguna tidak dapat menemukan langsung solusi yang dibutuhkannya sehingga pengguna harus berulang kali melakukan konsultasi.

\section{DAFTAR PUSTAKA}

1. Jogiyanto, Analisis \& Desain Sistem Informasi, Penerbit Andi Yogyakarta:2005

2. Tata Sutabri, Sistem Informasi Manajemen, Penerbit Andi Yogyakarta: 2005

3. Sri Kusumadewi, Artificial Intelligence (Teknik dan Aplikasinya), Penerbit Graha Ilmu Yogyakarta: 2003

4. Toto Suwarto, Mencari \& Memperbaiki Kerusakan Sepeda Motor 4-tak, Penerbit PT. Kawan Pustaka 2008

5. Sri Hartati Wijono, Pemrograman Java Servlet dan JSP dengan Netbeans, Penerbit Andi Yogyakarta: 2007 